\title{
Risk management system model to improve the reputation of oil and gas companies in the Java island - Indonesia
}

\author{
Nova Nevila Rodhi ${ }^{1,2,}$, I Putu Artama Wiguna ${ }^{2}$, and Nadjadji Anwar ${ }^{2}$ \\ ${ }^{1}$ Departement of Civil Engineering, Universitas Bojonegoro, Bojonegoro, Indonesia \\ ${ }^{2}$ Departement of Civil Engineering, Institut Teknologi Sepuluh Nopember, Surabaya, Indonesia
}

\begin{abstract}
Risk management has been widely studied and applied in oil and gas pipeline projects, but the reality is that the impacts still occur. This is due to the ineffectiveness of existing risk management applications, so of course in this case an effective risk management system is needed, in which risk management must pay attention to all aspects that exist, both internal aspects, external aspects, and other aspects that can affect and influenced by existing risks and risk management not only can be used as a preventive method. But it can also support sustainable development targets. This paper presents the application of risk management by oil and gas companies in Indonesia that has been adapted to ISO 31000:2009 as a framework that can integrate various other management processes, including the management of HSE (Health, Safety, and Environment) risk in the hope of that sustainable development can be achieved . But in the reality it can not be denied that the activities that continue to this day still cause negative impact, especially for the environment. International oil and gas companies nowadays place more emphasis on preventive measures than the methods of mitigation. Thus it shows that the concept of sustainable development has not been fully considered in risk management applications. The existence of a continuous negative impact would greatly affect the credibility of oil and gas companies. Based on the results of research conducted with the hybrid method and analyzed with the help of System Dynamics it can be concluded that there are 3 (three) factors that can affect reputation risk, these factors are social, environmental, and economic and the model built in this study shows that it will can help the oil and gas company players to predict and improve the company's reputation.
\end{abstract}

\section{Introduction}

The oil and gas projects have many risks that potentially become hazardous to life, property, and the environment if those activities are not properly controlled and regulated [1]. One of the activities at risk is the pipeline project. If there is a leak in the oil and gas

\footnotetext{
*Corresponding author: nova.nevila@gmail.com
} 
pipeline and often occurs in the negative impact, it can lead to social conflict and casualties. [2]. The existence of an impact due to the risk that is not managed correctly [3]. A risk is an internal or external situation that can affect and change the initial state and affect time, cost and security [4]. According to Nielsen (2006), the oil and gas pipeline project has very complex risk [5]. Ogwu (2011), states that the oil and gas pipeline project has enormous environmental, social, and economic impacts [6].

As explained by Hasan (2016) in his paper, that although the failure of the pipeline project is rare, but if the failure can have a significant impact on the social environment, it is because, in addition to many areas damaged by the incident, the failure of oil and gas pipeline also took a massive loss of life [4]. The impacts caused by the project in the oil and gas industry can affect the credibility of oil and gas companies, thus automatically affecting the sustainability of existing projects [7].

The risks contained in the oil and gas pipeline project can certainly be anticipated with risk management applications, but if risk management has been applied and still has a negative impact, it is one of them because the risk management application is not systematic and ineffective. Therefore, it is necessary to develop a concept of risk management that can build an effective risk management system [3].

Currently, oil and gas companies in Indonesia certainly have applied risk management. In general, risk management applied by some oil and gas companies is more emphasized in managing the risk of HSE (Health, Safety, and Environment) [8]. In ISO 31000:2009, it is mentioned that the effectiveness of risk management can be achieved by taking into account 11 (eleven) risk management principles. The risk management principle shows that it must be done concerning all aspects of the project management field so that risk management can help companies achieve their goals.

For risk management applications following the corporate characteristic certainly needed an effective method. Dynamics systems can be used to understand complex behavior and system dynamics over time [9]. Shin et al. (2013) state that dynamic systems can analyze feedback mechanisms. For example, an event $\mathrm{X}$ will affect the occurrence of $\mathrm{Z}$ and vice versa, in which case, of course, the event must be analyzed thoroughly and cannot be analyzed separately, where the analysis is only done on the effect of $\mathrm{X}$ to $\mathrm{Z}$ only or vice versa. The concept of feedback loop system analysis or causal loops is an advantage possessed by System Dynamics [10]. Based on the description above. This paper builds a model of the risk management system to improve the reputation of oil and gas companies in the Indonesian island of Java by using the method of System Dynamics.

\section{Literature review}

In Indonesia's oil and gas industries there are 2 (two) main activities, namely core business which consist of upstream business which includes exploration and exploitation. In the upstream business, there is also a downstream business which provides processing, transportation, storage, and trading. In addition to the core business, in the oil and gas industry, there are also supporting businesses which include construction services and nonconstruction services. One of the much needed supporting infrastructure in the project is a gas pipeline that serves to support the transmission and distribution of natural gas. Currently, the Indonesian government is targeting the construction of a transmission network with a length of $7558.3 \mathrm{~km}$ and a distribution network of $2733.15 \mathrm{~km}$ spread throughout the working area can be realized in 2018. The distribution pipeline network in Java is planned to be longer than in other areas, along $1244.15 \mathrm{~km}$ [11].

In an effort to achieve the target of pipeline development, oil and gas industry players will face various challenges and obstacles, whether from the risk of internal factors or external ones have a negative impact on the sustainability of the oil and gas pipeline project 
itself also to the surrounding environment. This can be seen from some of the harmful events that are caused by the oil and gas pipeline project, as well as the theft by punching holes in pipes which are very dangerous. The existence of a leakage pipe causes fire until the explosion of oil and gas pipelines in Rig Pumpindo Majalengka that claimed casualties and caused burns to residents [12]. The tragic events caused by pipeline projects also occur in some other countries. As explained by Hasan (2016) in his paper, that although the failure of the pipeline project is rare, but if the failure can have a massive impact on the social environment, it is because, in addition to many areas damaged by the incident, the failure of oil and gas pipeline also took a massive loss of life. The impacts caused by the project in the oil and gas industry can affect the credibility of oil and gas companies, thus automatically affecting the sustainability of existing projects [7].

Currently, in addition to the principles that must be adhered to also there is a concept that must be considered and taken into account in every activity. It is a concept of sustainable development [13]. Sustainable development is a development concept that aims to provide a better quality of life for all people, both at present and in future generations [14]. Thus, construction project risk management must be taking into consideration the concept of sustainable development so that the planned project can achieve a sustainable construction project and can support sustainable development targets [15].

Sustainable Construction Project is a project that is based on balance, whether it be a financial balance, environment and operational considerations on all existing processes [16]. The concept can inspire the engineer of construction services and other project actors regarding determining methods and planning to achieve project implementation efficiency. Among them is done by integrating the preparation of mapping design and project process to be undertaken [17], as well as by project scheduling [18].

In order to achieve a sustainable construction project requires an effective and acceptable method by all parties. This can be done by security risk management considering at the design and planning stage, building efficient designer and constructor communication, and effective planning and safety management during construction. [19] According to Bakhtiari, risk management is an essential tool for achieving sustainable development, as risk management is a crucial key to maximizing sustainable development goals [20].

To achieve sustainable development, construction project risk management must be carried out concerning the objectives of Sustainable Development Goals, which achieve sustainable development and lift people out of poverty. In the effort to alleviate poverty, it must be accompanied by economic growth, so that all kinds of risks that could adversely affect economic growth must be well managed, including those related to disaster risk and vulnerability in the development plan. This is because disaster can be a significant threat in achieving and sustaining development plans and objectives [20].

Dynamics systems can be used to understand complex behavior and system dynamics over time [9]. Yames mentions the model built with systems approach which has 4 (four) virtues [21], namely 1) enable conducting cross-sectoral research with broad scope, 2) can experiment with the system without disturbing (giving treatment) pertain to the system, 3) able to determine the purpose of management activities and improvements to the system under study, and 4) can be used to predict (predict) behavior and state of the system in the future.

\section{Research methods}

In this research is done by using a hybrid method, where preliminary data obtained based on the identification of literature review which then continued with validation based on 
respondent perspective. In this study, related respondents are employees of oil and gas companies in the island of Java Indonesia.

System modeling starts from the system conceptualization stage which is done by building a conceptual model illustrated with the Causal Loop Diagram (CLD). It aims to describe the simulation of System Dynamics that will be carried out in general, where this diagram is formed based on the variables that already exist. This conceptualization phase will produce a causal diagram which will then be combined into a complete system

The design of respondents used in this study is the design of respondents remain because the respondents formed following specific rules and do not change during the process of withdrawal of respondents take place. The design of fixed respondent chosen in this research is the cluster sampling method, which is a technique to select a respondent from a small group of clusters or clusters.

\section{Results and discussion}

From the literature, there are three variables can affect the reputation risk of oil and gas companies. Namely, social, economic, and environmental. Furthermore, it can be explained that each variable has parameters that can affect each other. The identification results are validated with the actual situation by distributing questionnaires and assessing the risks to each variable. The variables are presented in Table 1. From Table 1, risk analysis is performed to obtain the most dominant variables and will be used in the preparation of this research model. The initial stage analysis results can be seen in Table 2 .

Table 2 presents seven parameters affect social risk, while for economic risk the origin has five parameters into two parameters, as well as for the environment, which initially has eight parameters, after analyzing there are only two parameters. To shorten the parameter names in the model, in this case, a code is created for each parameter.

Referred to in Table 2 then, in this case, can be built model premises to describe the causal loop diagram first, as for the basic model CLD can be seen in Fig. 1 below:

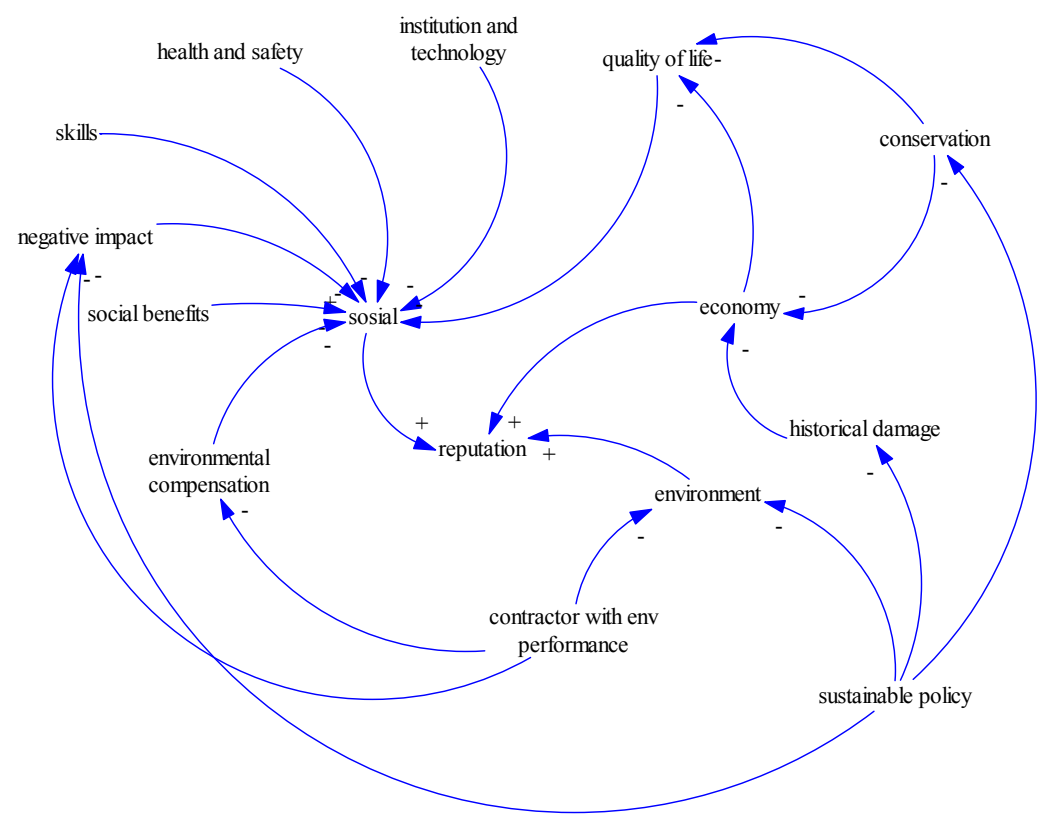

Fig. 1. Causal Loop Diagram (CLD) of the basic model. 
Table 1. Risk variables of oil and gas pipeline project in Indonesia.

\begin{tabular}{|c|c|c|}
\hline Variables & Parameters & Resources \\
\hline \multirow{7}{*}{ Social } & Improving the quality of human life with poverty alleviation & \multirow{20}{*}{$\begin{array}{l}{[13],[18],[22],} \\
{[23],[24],[25],} \\
{[26],[27],[28],} \\
{[29],[30],[31]}\end{array}$} \\
\hline & $\begin{array}{l}\text { Planning that can be adapted by local human institutions and } \\
\text { technologies }\end{array}$ & \\
\hline & Health and safety & \\
\hline & The skills of the people who participated in the project & \\
\hline & Avoids the negative social impact of construction works & \\
\hline & $\begin{array}{l}\text { Social benefits during construction (eg, employment } \\
\text { opportunities) }\end{array}$ & \\
\hline & Equal compensation for environmental change & \\
\hline \multirow{5}{*}{ Economy } & financial affordability & \\
\hline & Employment Opportunity & \\
\hline & $\begin{array}{l}\text { Full cost accounting balance and real costing related to efficiency } \\
\text { in the process }\end{array}$ & \\
\hline & $\begin{array}{l}\text { Improve market competitiveness by adopting policies and } \\
\text { practices that promote sustainability issues }\end{array}$ & \\
\hline & $\begin{array}{l}\text { Selects environmentally-responsible suppliers and contractors } \\
\text { that can demonstrate environmental performance }\end{array}$ & \\
\hline \multirow{8}{*}{ Environment } & $\begin{array}{l}\text { Reduce the use of four common sources used in construction, } \\
\text { energy, water, materials, and land, at each stage of the project } \\
\text { life cycle (REDUCE) }\end{array}$ & \\
\hline & $\begin{array}{l}\text { Maximizing resource reuse, and/ or recycling to reduce waste } \\
\text { (REUSE) }\end{array}$ & \\
\hline & $\begin{array}{l}\text { Recycling (reduction of raw materials used in new products) } \\
\text { (RECYCLE) }\end{array}$ & \\
\hline & $\begin{array}{l}\text { Use renewable resources to choose non-renewable resources } \\
\text { (RENEWABLE) }\end{array}$ & \\
\hline & Minimize air, soil, and water pollution & \\
\hline & $\begin{array}{l}\text { Create and use environmentally friendly products in } \\
\text { construction, on human health and safety and minimize } \\
\text { environmental damage. }\end{array}$ & \\
\hline & $\begin{array}{l}\text { Conservation efforts by conserving life support systems, } \\
\text { conserving plant biodiversity, animals, and other organisms }\end{array}$ & \\
\hline & $\begin{array}{l}\text { Minimizes damage to sensitive landscapes, including valuable } \\
\text { areas from a landscape, cultural, historical, or architectural point } \\
\text { of view, and minimizes disturbance to the wilderness area }\end{array}$ & \\
\hline
\end{tabular}


Table 2. Variables used in the model.

\begin{tabular}{|c|c|c|}
\hline Variables & Parameters & Code \\
\hline \multirow{7}{*}{ Social } & Improving the quality of human life with poverty alleviation & Quality of life \\
\hline & $\begin{array}{l}\text { Planning that can be adapted by local human institutions and } \\
\text { technologies }\end{array}$ & $\begin{array}{l}\text { Institutions and } \\
\text { technology }\end{array}$ \\
\hline & Health and safety & Health and safety \\
\hline & The skills of the people who participated in the project & Skills in the project \\
\hline & Avoids the negative social impact of construction works & Negative impact \\
\hline & $\begin{array}{l}\text { Social benefits during construction (eg, employment } \\
\text { opportunities) }\end{array}$ & Social benefits \\
\hline & Equal compensation for environmental change & $\begin{array}{l}\text { Environmental } \\
\text { compensation }\end{array}$ \\
\hline \multirow[b]{2}{*}{ Economy } & $\begin{array}{l}\text { Improve market competitiveness by adopting policies and } \\
\text { practices that promote sustainability issues }\end{array}$ & Sustainable policy \\
\hline & $\begin{array}{l}\text { Selects environmentally-responsible suppliers and } \\
\text { contractors that can demonstrate environmental performance }\end{array}$ & $\begin{array}{l}\text { Contractor with } \\
\text { environmental } \\
\text { performance }\end{array}$ \\
\hline \multirow[b]{2}{*}{ Environment } & $\begin{array}{l}\text { Conservation efforts by conserving life support systems, } \\
\text { conserving plant biodiversity, animals and other organisms }\end{array}$ & Conservation efforts \\
\hline & $\begin{array}{l}\text { Minimizes damage to sensitive landscapes, including } \\
\text { valuable areas from a landscape, cultural, historical, or } \\
\text { architectural point of view, and minimizes disturbance to the } \\
\text { wilderness area }\end{array}$ & Historical damage \\
\hline
\end{tabular}

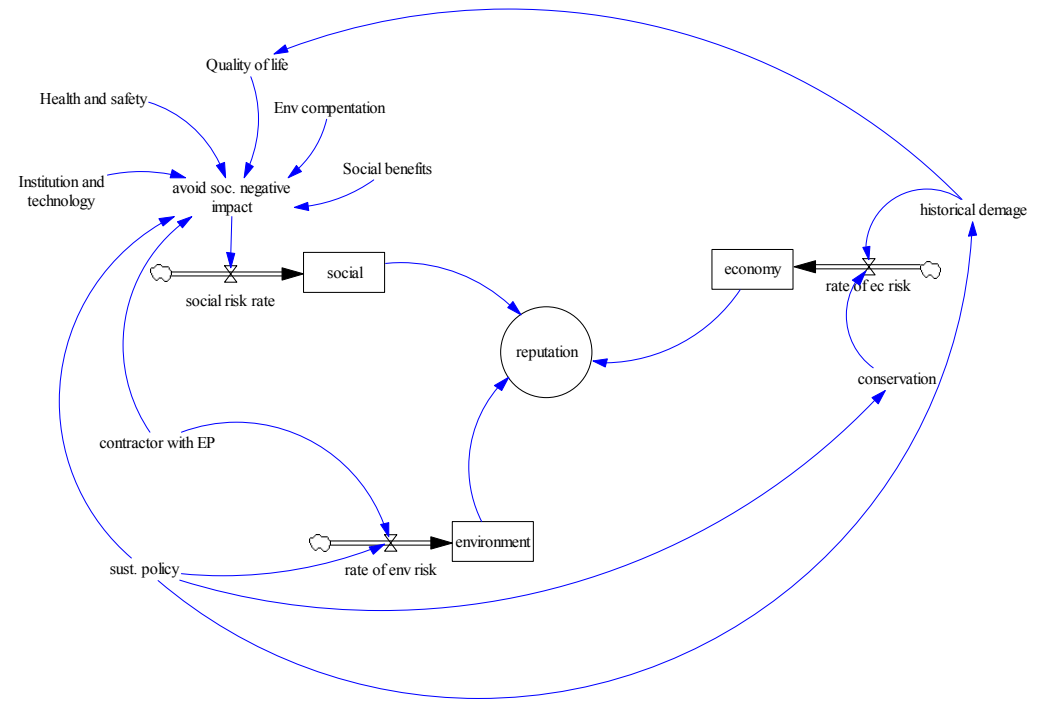

Fig. 2. Stock and Flow Diagram (SFD) of the basic model. 
Fig. 2 is the based-model reputation of oil and gas companies. The model consists of 3 sub-based models, namely social sub-models, economic sub-models, and environmental sub-models.

In the CLD explained that there are three main variables which can affect the reputation of oil and gas companies, these variables are social, economic, and environmental. Each variable is influenced by several parameters, and it can affect as an amplifier and also as a counterweight to the existing variables. Besides that, among parameters can also influence each other. After the relationship between variables is known, then the CLD can be developed into stock and flow diagrams.

\section{Conclusions}

Based on the results of the discussion on point 4 Fig. 2 can be concluded that there are 3 (three) factors that can affect the reputation risk, namely social, environment, and economy and the model built System Dynamics in this research shows can help the perpetrators oil and gas companies to predict and enhance the company's reputation. It is based on a causal relationship between the variables. As for the relationships that are built, among others, the relationship of loop balancing and reinforcing loop.

\section{References}

1. O.W. Achaw, E.D. Boateng, Int. J. of Development and Sustainability 1, 2 (2012)

2. D. Ambarsari, Minyak kami tanggung jawab kami-transparansi migas untuk pembangunan berkelanjutan: belajar dari Blora dan Bojonegoro (2009)

3. N.V. Thuyet, S.O. Ogunlana, P.K. Dey, Int. J. of Energy Sector Man. 1, 2 (2007)

4. A. Hasan, J. of Pipeline Systems Eng. and Practice 7, 3 (2016)

5. S. Nasution, Y. Arkeman, K. Soewardi, T. Djatna, J. of Industrial Res. 8, 2 (2016)

6. F.A. Ogwu, FORUM Ejournal 10 (2011)

7. H. Conner, Managing environmental risk in the oil and gas industry (Thesis, Claremont Graduate University, California, 2015)

8. Y.A. Cintya, Implementasi Standar Internasional ISO 31000: 2009 risk management -principles and guidelines di sektor energi-minyak dan gas. Available at: http://crmsindonesia.org/www2/knowledge/crms-articles/implementasi-standarinternasional-iso-31000-2009-risk-management-\%E2\%80\%93 (2014)

9. Y.M Goh, P.E.D. Love, Safety Science 50 (2012)

10. M. Shin, H.S. Lee, M. Park, M. Moon, M, S. Han, Accident Analysis and Prevention 68 (2013)

11. Kementerian Energi dan Sumber Daya Mineral. Peluang investasi sektor ESDM (Menteri Energi dan Sumber Daya Mineral, Jakarta, 2011)

12. T. Purwati, Pipa gas dan minyak Pertamina meledak, 1 tewas. Available at: www.pikiran-rakyat.com/jawa-barat/2016/02/08/360129/pipa-gas-dan-minyakpertamina-meledak-1-tewas (2016)

13. G. Nyirenda, C.C. Ngwakwe, J. of Env. Economics 5, 1 (2014)

14. M. Abduh, Seminar Nasional Sustainability dalam Bidang Material, Rekayasa, dan Konstruksi Beton (2007)

15. C.S. Goh, S. Rowlinson, J. of Legal Affairs and Dispute Resolution in Engineering and Construction 5, 4 (2013) 
16. L.Kh.M. Suliman., dan A. Omran, Journal of Economic, Social, Political, and Cultural Problems of the Future Society 10 (2009)

17. S. Asad, M.M.A. Khalfan, Emirates J. for Eng. Research 12, 2 (2007)

18. J. Irizarry, S. Zolfagharian, M. Nourbakhsh, Zin, M. Rosli, K. Jusoff, R Zakariya, J. of Information Technology in Construction 17 (2012)

19. K.S. Dewlaney, M.R. Hallowell, B.R. Fortunato, J. of Construction Engineering And Management 138, 8 (2012)

20. S. Bakhtiari, OIDA Int. Journal of Sustainable Development (2014)

21. Y. Barlas, European J. of Operational Research 42, 1 (1996)

22. U. Rosentröm, The J. of Transdisciplinary Environmental Studies 5, 1-2 (2006)

23. B. Masood, Postmodernism and architecture (Khak publication, Iran, 2007)

24. E.S. Bakhoum, D.C. Brown, J. of Construction Eng. and Man. 138, 1 (2012)

25. El Attar, W. Khattab, Proc. of the Int. Maritime Transport \& Logistics Conf. (2013)

26. N. Wang, K. Wei, H. Sun, J. of Man. in Eng. 30, 2 (2014)

27. D. Paton, D. Johnston, L. Mamula-Seadon, C.M. Kenney, Disaster \& development: examining global issues and cases (Springer, New York, 2014)

28. H. Zabihi, F. Habib, L. Mirsaeedi, Int. J. of Emerging Sciences 2, 4 (2012)

29. W.N.B. Osman, Z.M. Udin, D. Salleh, J. of Southeast Asian Res. 2012 (2012)

30. J. Morelli, J. of Environmental Sustainability 1, 1 (2011)

31. S. Zolfagharian, M. Nourbakhsh, J. Irizarry, A. Ressang, M. Gheisari, Construction Research Congress 2012 (2012) 